\title{
Gambaran Hasil Pemeriksaan HIV pada Darah Donor
}

\author{
Overview of HIV Test Results on Donor Blood
}

\section{BAGUS TRIATMOJO}

\author{
UTD PMI Kabupaten Jepara \\ Jl. Jepara - Bangsri, Kuwasen IV, Kuwasen, Jepara \\ Email: bagustriatmojopmi@gmail.com
}

\begin{abstract}
Abstrak
Kasus HIV pada beberapa tahun terakhir menuntut atas penanganan dari beberapa aspek secara bersamaan termasuk unit transfusi darah (UTD). HIV dapat menular melalui transfusi darah maupun produk darah lainnya. UTD PMI Kabupaten Jepara melaksanakan rekrutmen donor sukarela yang berasal dari masyarakat Jepara. Pemeriksaan HIV sebagai bagian uji saring IMLTD dilakukan untuk keamanan darah donor. Pemeriksaan HIV pada semua darah donor menggunakan metode rapid dan elisa. Hasil pemeriksaan dinyatakan dalam reaktif dan non reaktif. Tujuan penelitian untuk mengetahui gambaran hasil pemeriksaan HIV darah donor di UTD PMI Kabupaten Jepara pada tahun 2019. Jenis penelitian deskriptif menggunakan catatan data pendonor di UTD PMI Kabupaten Jepara Tahun 2019. Hasil penelitian HIV reaktif sebanyak 12 darah donor $(0,08 \%)$. HIV non reaktif pendonor usia $<18$ tahun, 18-24, 25-44, 45-59, dan usia $\geq 60$ tahun secara berturut-turut adalah 9,55\%, 22,39\%, $51,75 \%, 16,01 \%$, dan $0,21 \%$. HIV reaktif pendonor kelompok usia 18-24, 25-44, dan 45-59 tahun sebanyak $0,034 \%, 0,034 \%$, dan $0,13 \%$. HIV non reaktif pada laki-laki $68,22 \%$ dan pada perempuan $31,70 \%$. HIV reaktif pada laki-laki $0,067 \%$, dan perempuan $0,013 \%$. HIV non reaktif pada darah donor sukarela sebesar $99,779 \%$ dan donor pengganti $0,127 \%$. HIV reaktif darah donor sukarela sebesar $0,074 \%$, dan donor pengganti $0,007 \%$. Uji saring HIV sangat diperlukan untuk keamanan darah karena usia, jenis kelamin dan jenis darah donor memiliki potensi HIV reaktif.
\end{abstract}

Kata Kunci : HIV ; Darah Donor ; PMI

\section{Abstract}

$H I V$ cases in Jepara District in recent years have demanded the handling of several aspects simultaneously including the Blood Transfusion Unit (BTU). HIV can be transmitted through blood transfusion or other blood products. BTU of PMI Jepara Regency carries out recruitment of voluntary donor from Jepara society. The HIV examination as part of an IMLTD screening test is done for safety of donor blood. The HIV examination in all donor blood uses rapid and elisa method. Examination results are stated as reactive and non reactive. Research objective to find out the description of HIV examination results in donor blood at the BTU of PMI Kabupaten Jepara in 2019. Research method the research type was descriptive using records of donor data at BTU of PMI Kabupaten Jepara in 2019. The examination results of reactive HIV in 12 donor blood (0,08\%). non-reactive blood donor of $H I V$ in age groups $<18$ years, 18-24, 25-44, 45-59, and $\geq 60$ years respectively 9,55\%, $22,39 \%, 51,75 \%, 16,01 \%$ and $0,21 \%$. Reactive HIV in age groups 18-24, 25-44, and 45-59 years were $0,034 \%, 0,034 \%$, and $0,13 \%$. Non-reactive HIV in men $68,22 \%$ and in women $31,70 \%$. Reactive HIV in men $0,07 \%$, and women $0,01 \%$. Non-reactive HIV in voluntary donor blood was $99,779 \%$ and substitute donor was $0,127 \%$. HIV of reactive voluntary donor blood was $0,074 \%$, and substitute donor was 0,007\%. HIV filter test is indispensable for blood safety because the age, gender and blood type of donors have the potential for reactive $H I V$. 


\section{Pendahuluan}

Pelayanan transfusi darah oleh Unit Transfusi Darah PMI sebagai salah satu upaya kesehatan membutuhkan ketersediaan darah atau komponen darah yang cukup, aman, mudah diakses dan terjangkau oleh masyarakat. Kegiatan penyediaan darah dimulai dari rekrutmen pendonor sukarela, seleksi donor, pengolahan darah, uji saring darah, penyimpanan darah sampai distribusi darah (Peraturan Menteri Kesehatan No. 91, 2015).

Darah yang digunakan berasal dari donor darah sukarela, yaitu orang yang memberikan darah, plasma atau komponen darah lain atas kerelaan sendiri. Donor darah sukarela memiliki risiko rendah dibandingkan dengan donor darah pengganti ataupun donor darah komersial / bayaran karena DDS menyumbangkan darah secara teratur setiap 2,5-3 bulan. Pemeriksaan skrining darah dilakukan setiap kali darah disumbangkan sehingga bila DDS rutin melakukan donor darah maka darahnya akan terkontrol. Data menyebutkan bahwa sebagian besar donasi darah berasal dari donor laki-laki $(68,68 \%)$, dan donor perempuan sebesar 22,22\%. Kelompok usia 25-44 tahun sebagai donor terbesar yaitu 48,7\% (Kementerian Kesehatan, 2016).

Uji saring Infeksi Menular Lewat Transfusi Darah merupakan bagian yang kritis dari proses penjaminan darah. Konseling sebelum pengambilan darah dengan memberikan informasi bahwa akan dilakukan uji saring / skrining terhadap penyakit infeksi, meliputi HIV, hepatitis $\mathrm{B}$, hepatitis $\mathrm{C}$, dan sifilis. Hasil pemeriksaan darah donor reaktif, maka darah tidak dapat didonorkan (Peraturan Menteri Kesehatan No. 91, 2015).

PMI melaksanakan rekrutmen pendonor sukarela yang berasal dari masyarakat Jepara. Hasil uji saring darah menyatakan keadaan pendonor meliputi memenuhi syarat donor, donor cekal permanen, dan donor cekal sementara. Pendonor cekal permanen tidak memungkinkan menyumbangkan darah seusia hidupnya disebabkan darah terinfeksi penyakit HIV. Cekal sementara menandakan pendonor untuk sementara waktu tidak dapat menyumbangkan darahnya karena alasan medis. Menurut Profil Dinas Kesehatan Kabupaten Jepara Tahun 2018, kasus HIV di seluruh Kabupaten Jepara mencapai 169 orang (DKK Jepara, 2019). Hasil penghitungan ini termasuk didalamnya hasil uji skrining darah donor melalui UTD PMI Kabupaten Jepara. Kasus darah donor reaktif HIV di UTD PMI Kabupaten Jepara perlu untuk dilakukan penelitian lebih lanjut.

\section{Metode}

Jenis penelitian adalah penelitian deskriptif dengan rancangan non eksperimental dengan pendekatan cross sectional. Populasi pada penelitian ini adalah seluruh darah donor di UTD PMI Kabupaten Jepara tahun 2019 yang dilakukan uji saring IMLTD. Sampel yang diambil adalah seluruh darah donor dengan hasil reaktif dan non reaktif HIV menggunakan metode rapid tes dan ELISA.

\section{Hasil dan Pembahasan}

Data penelitian yang diperoleh darah donor setelah dilakukan konfirmasi sebanyak 14.907. Data pendonor dibagi berdasarkan jenis kelamin, kelompok usia, dan asal darah. Kelompok usia meliputi $<18$ tahun, 18-24 tahun, 25-44 tahun, 45-59 tahun, dan lebih dari 60 tahun. Asal darah donor dari donor sukarela (DS), dan donor pengganti (DP). 
Tabel 1 Persentase hasil pemeriksaan HIV pada darah donor berdasar kelompok usia

\begin{tabular}{ccccccc}
\hline \multirow{2}{*}{ Kelompok Usia (tahun) } & \multicolumn{2}{c}{ Reaktif } & \multicolumn{2}{c}{ Non Reaktif } & \multicolumn{2}{c}{ Jumlah } \\
& $\mathrm{n}$ & $\%$ & $\mathrm{n}$ & $\%$ & $\mathrm{n}$ & $\%$ \\
\hline$<18$ & 0 & 0 & 1424 & 9,553 & 1424 & 9,553 \\
$18-24$ & 5 & 0,034 & 3338 & 22,392 & 3343 & 22,426 \\
$25-44$ & 5 & 0,034 & 7715 & 51,754 & 7720 & 51,788 \\
$45-59$ & 2 & 0,013 & 2386 & 16,006 & 2388 & 16,019 \\
$\geq 60$ & 0 & 0 & 32 & 0,215 & 32 & 0,215 \\
Jumlah & 12 & 0,080 & 14895 & 99,920 & 14907 & 100,00 \\
\hline
\end{tabular}

Tabel 1 menyebutkan HIV reaktif sebanyak 12 darah donor $(0,08 \%)$ berasal dari pendonor kelompok usia 18-24, dan 25-44 tahun masing-masing 5 pendonor $(0,034 \%)$, dan usia 45-59 tahun sebanyak 2 pendonor $(0,013 \%)$.

Tabel 2 Persentase hasil pemeriksaan HIV berdasarkan jenis darah donor

\begin{tabular}{cccccccccccc}
\hline & \multicolumn{3}{c}{ Donor Sukarela } & \multicolumn{3}{c}{ Donor Pengganti } \\
Kelompok & Reaktif & Non Reaktif & Reaktif & \multicolumn{2}{c}{ Non } \\
Usia (tahun) & Reaktif & & Jumlah \\
& $\mathrm{n}$ & $\%$ & $\mathrm{n}$ & $\%$ & $\mathrm{n}$ & $\%$ & $\mathrm{n}$ & $\%$ & $\mathrm{n}$ & $\%$ \\
\hline$<18$ & 0 & 0 & 1424 & 9,553 & 0 & 0 & 0 & 0 & 1424 & 9,553 \\
$18-24$ & 5 & 0,034 & 3338 & 22,392 & 0 & 0 & 0 & 0 & 3343 & 22,426 \\
$25-44$ & 4 & 0,027 & 7696 & 51,627 & 1 & 0,007 & 19 & 0,127 & 7720 & 51,788 \\
$45-59$ & 2 & 0,013 & 2384 & 15,992 & 0 & 0 & 2 & 0 & 2388 & 16,019 \\
$\geq 60$ & 0 & 0 & 32 & 0,215 & 0 & 0 & 0 & 0 & 32 & 0,215 \\
Jumlah & 11 & 0,074 & 14874 & 99,779 & 1 & 0,007 & 21 & 0,127 & 14907 & 100,00 \\
\hline
\end{tabular}

Tabel 2 menyebutkan bahwa pada donor sukarela diperoleh HIV reaktif sebanyak 11 sampel $(0,074 \%)$ berasal dari kelompok usia $18-24$ tahun sebanyak $0,034 \%$, usia $25-44$ tahun sebanyak $0,027 \%$, dan $45-49$ tahun sebanyak $0,13 \%$. Donor pengganti reaktif hanya 1 sampel $(0,007 \%)$ berasal dari pendonor berusia $25-44$ tahun. 
Tabel 3 Persentase hasil pemeriksaan HIV darah donor berdasar jenis kelamin

\begin{tabular}{ccccccc}
\hline Jenis Kelamin & \multicolumn{2}{c}{ Reaktif } & \multicolumn{2}{c}{ Non Reaktif } & \multicolumn{2}{c}{ Jumlah } \\
& $\mathrm{n}$ & $\%$ & $\mathrm{n}$ & $\%$ & $\mathrm{n}$ & $\%$ \\
\hline Laki-laki & 10 & 0,067 & 10169 & 68,216 & 10179 & 68,28 \\
Perempuan & 2 & 0,013 & 4726 & 31,703 & 4728 & 31,72 \\
Jumlah & 12 & 0,080 & 14895 & 99,920 & 14907 & 100,000 \\
\hline
\end{tabular}

Tabel 3 menyebutkan HIV reaktif dari seluruh sampel adalah 12 pendonor $(0,08 \%)$. HIV reaktif pendonor laki-laki sebanyak $10(0,067 \%)$ dan $2(0,013 \%$ pendonor perempuan.

\section{Simpulan dan Saran}

\section{Simpulan}

HIV reaktif sebanyak 12 darah donor $(0,08 \%)$. HIV non reaktif pendonor usia $<18$ tahun, $18-24,25-44,45-59$, dan usia $\geq 60$ tahun secara berturut-turut adalah 9,55\%, 22,39\%, $51,75 \%, 16,01 \%$, dan $0,21 \%$. HIV reaktif pendonor kelompok usia 18-24, 25-44, dan 45-59 tahun sebanyak $0,034 \%, 0,034 \%$, dan $0,13 \%$. HIV non reaktif pada laki-laki $68,22 \%$ dan pada perempuan $31,70 \%$. HIV reaktif pada laki-laki $0,067 \%$, dan perempuan $0,013 \%$. HIV non reaktif pada darah donor sukarela sebesar $99,779 \%$ dan donor pengganti $0,127 \%$. HIV reaktif darah donor sukarela sebesar $0,074 \%$, dan donor pengganti $0,007 \%$.

\section{Saran}

Bagi petugas PMI dapat memberikan informasi dan keyakinan bahwa darah donor yang akan diberikan aman, karena darah yang tidak lolos uji saring segera dimusnahkan.

\section{Daftar Pustaka}

Aminah, S. (2015). HIV Reaktif pada Calon Donor Darah di Unit Donor Darah (UDD) Pembina Palang Merah Indonesia (PMI) Provinsi Lampung dan Unit Transfusi Darah PMI RSUD Pringsewu tahun 2010 - 2014. Lampung. Jurnal Analis Kesehatan, 4(2), 427-435.

Astuti, W. D., dan Laksono, A. D. (2013). Keamanan Darah Di Indonesia Potret Keamanan Transfusi Darah di Daerah Tertinggal, Perbatasan dan Kepulauan. Surabaya: Health Advocacy.

Dinas Kesehatan Kabupaten Jepara. (2019). Profil Dinas Kesehatan Kabupaten Jepara Tahun 2018.

Febrina, Riry. (2018). Human Immunodeficiency Virus - Acquired Immunodeficiency Syndrome dengan Sarkoma Kaposi Jurnal Kesehatan Andalas. 2018; 7(Supplement 3)

Hutapea. (2011). AIDS \& PMS dan Perkosaan. Jakarta: Rineka Cipta.

Kementerian Kesehatan Republik Indonesia. (2016). Situasi dan Analisis HIV AIDS di Indonesia. Pusat Data dan Informasi. Jakarta

Koraag, J. F. (2010). Berbagi Nyawa, Hidup Bahagia dengan Berdonor Darah. Yogyakarta: Pustaka Marwa.

R, Marlina. (2018). Karakteristik Pendonor Darah dengan HIV Reaktif Positif Melalui Rapid Test HIV Tiga Metode. Global Medical and Health Communication. Vol. 6 (1) Fakultas Kedokteran, Universitas Methodist Indonesia. Medan

Naroeni, A. (2009). Karakterisasi Galur HIV Indonesia Dari Donor Darah dengan Hasil Uji Serologi HIV Indeterminate. Makara Kesehatan. Vol 13 (1).15-21 
Peraturan Menteri Kesehatan Republik Indonesia Nomor 83 Tahun 2014 Tentang Unit Transfusi Darah, Bank Darah Rumah Sakit, dan Jejaring Pelayanan Transfusi Darah. Diakses pada tanggal 110 April 2020 dari https://www.kemhan.go.id/itjen/wp-content/uploads/2017/03/bn36-2016.pdf

Peraturan Menteri Kesehatan Republik Indonesia Nomor 91 tahun 2015 tentang Standar Pelayanan Tranfusi Darah. Jakarta. Diakses tanggal 1 April 2020 . http://hukor.kemkes.go.id/uploads/produk hukum/PMK_No.91 ttg_Standar Transfu si Pelayanan Darah .pdf

Ratih, W. (2012). Strategi Pemeriksaan Laboratorium Anti HIV. Jurnal Farmasi Sains dan Komunitas, Vol 9(2). 98-103

Suryani, Ulfah. (2015). Metode Nucleic Acid Test Untuk Uji Saring Virus Hepatitis B Pada Darah Donor Dengan Hepatitis B Occult. Jurnal Biotek Medisiana Indonesia. Vol 4(2)

Yaqin, A. A. (2017). Transfusi Darah. Retrieved 04/01/2020 from https://www.academia.edu/10329743/transfusidarah 